\title{
Pemantauan dan Pengendalian Kelembapan, Suhu, dan Intensitas Cahaya Tanaman Tomat dengan Logika Fuzzy Berbasis IoT
}

\author{
Sumantri K Risandriya*, Rifqi Amalya Fatekha, dan Sandy Aji Fitriansyah \\ Politeknik Negeri Batam, Batam, Indonesia \\ *Email: sumantri@polibatam.ac.id
}

\begin{abstract}
Pengendalian dan pemantauan kelembapan, suhu dan intensitas cahaya saat ini masih menggunakan cara yang manual yaitu dengan penyiraman atau penggunaan rumah kaca. Namun, karena kesibukan ditempat kerja dan terbatasnya waktu menyebabkan pengendalian kondisi tanaman tomat sering tidak sesuai dengan kebutuhan tanaman dan mengakibatkan tanaman mati. Penelitian ini menggunakan kontrol otomatis dari logika Fuzzy dan Internet of Things (IoT) sebagai dasar pemantauan kondisi tanaman tomat dengan tugas menggantikan perawatan manual. Sensor DHT22, FC-28 dan Light Dependent Resistor (LDR) digunakan sebagai pendeteksi kelembapan tanah, suhu, intensitas cahaya, dan kelembapan udara, serta parameter input sebagai kontrol Fuzzy yang otomatis, serta aktuator penyiraman pompa air DC $12 \mathrm{~V}$ dan motor power window sebagai pengendali kelembapan udara. Hasil pada penelitian ini memiliki tingkat keberhasilan $\mathbf{9 8 . 3 8 \%}$ dalam proses kerjanya.
\end{abstract}

Kata kunci: Logika Fuzzy, tanaman tomat, monitoring, IoT, kelembapan, suhu, intensitas cahaya

\section{Pendahuluan}

TANAMAN tomat (Lycopersion esculentum Miil) merupakan adalah salah satu tanaman yang pertumbuhannya perlu dikendalikan. Menurut Balai Besar Pelatihan Pertanian (BBPP) Lembang, kondisi yang sesuai untuk tanaman tomat adalah $24^{\circ}-28^{\circ} \mathrm{C}$ untuk temperature dan $80 \%$ untuk kelembapan. Sedangkan intensitas cahaya berfungsi sebagai media fotosintesis yang dibutuhkan oleh setiap tanaman. Namun, untuk mengurangi dan mempermudah pekerjaan manusia dalam memantau dan mengatur kondisi lingkungan, maka diperlukan sebuah kontrol otomatis dan pengawasan dari jarak jauh.

Dengan latar belakang permasalahan tersebut, penulis membuat sebuah sistem yang dapat mengatur kondisi lingkungan yang sesuai dengan tanaman serta dapat diawasi dari jarak jauh. Pengaturan kelembapan, suhu, dan intensitas cahaya diatur dengan metode logika Fuzzy, sedangkan pengawasan jarak jauh menggunakan Internet of Things (IoT), yang diharapkan mampu menyelesaikan, mengurangi dan mempermudah pekerjaan bagi para petani tomat.

\section{TEORI}

\section{A. Tanaman Tomat}

Tomat merupakan sayuran buah yang tergolong tanaman semusim berbentuk perdu dan termasuk ke dalam famili Solanacea [1]. Temperatur ideal dan berpengaruh baik terhadap warna buah tomat adalah antara $24^{\circ} \mathrm{C}-28^{\circ} \mathrm{C}$ yang umumnya merah merata. Keadaan temperatur dan kelembapan yang tinggi berpengaruh kurang baik terhadap pertumbuhan, produksi dan kualitas buah tomat. Kelembapan yang relatif diperlukan untuk tanaman tomat adalah $80 \%$ [2].

\section{B. Logika Fuzzy}

Logika Fuzzy merupakan sebuah sistem yang dikembangkan dari sistem Boolean klasik dimana input dan output yang dihasilkan memiliki pilihan keanggotaan yang semakin banyak mulai dari 0 dan 1 [3]. Sistem Fuzzy mirip dengan konsep berfikir manusia yang dirubah ke dalam bentuk matematis, sehingga pengaturan dan pengendaliannya dipengaruhi oleh informasi dari pengalaman yang ada di dunia nyata. Perbedaan logika Boolean dengan logika Fuzzy dapat dilihat pada Gambar 1.

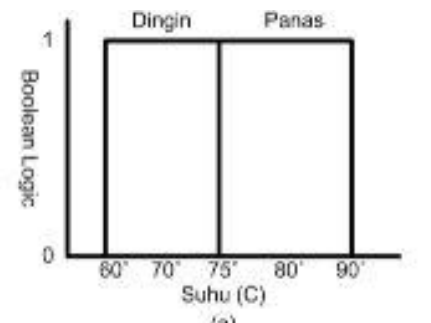

(a)

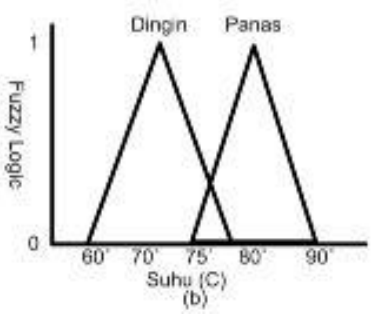

(b)
Gambar 1. Logika Boolean dan logika Fuzzy

Hal-hal yang perlu diketahui dalam memahami sistem kontrol Fuzzy adalah sebagai berikut:

1) Fuzifikasi

Fuzifikasi merupakan sebuah proses mengubah nilai input berbentuk tegas (crisp) menjadi input berbentuk Fuzzy (variabel linguistik) [4]. Nilai input Fuzzy ditampilkan dalam bentuk himpunan Fuzzy dengan fungsi 
keanggotaannya masing-masing sesuai dengan intuisi manusia [5].

2) Evaluasi Aturan

Evaluasi aturan merupakan sebuah proses untuk mengambil keputusan berupa variabel Fuzzy output (penyelesaian), yaitu himpunan-himpunan output Fuzzy dengan fungsi keanggotaan yang ditetapkan berdasarkan metode yang digunakan. Kondisi-kondisi yang dibandingkan berdasarkan basis aturan yang telah dibuat serta penalaran dari penciptanya.

3) Defuzifikasi

Defuzifikasi merupakan sebuah proses yang berlawanan dengan proses Fuzifikasi. Dimana proses ini mengubah himpunan Fuzzy (variabel linguistik) menjadi himpunan dengan bentuk tegas (crisp). Metode defuzifikasi yang digunakan pada penelitian ini adalah metode Center of Area (COA). Metode ini menggunakan titik pusat $\left(\mathrm{z}^{*}\right)$ daerah Fuzzy untuk memperoleh solusi crisp. Secara umum dirumuskan pada persamaan (1) [5], di mana $z^{*}$ adalah titik pusat daerah output Fuzzy, $\mu\left(z_{i}\right)$ adalah nilai perbandingan min keanggotaan Fuzzy, dan $z_{i}$ adalah nilai keanggotaan output Fuzzy.

$$
z^{*}=\frac{\sum \mu\left(z_{i}\right) \cdot z_{i}}{\sum \mu\left(z_{i}\right)}
$$

\section{Himpunan Fuzzy}

Himpunan Fuzzy merupakan pengelompokkan suatu nilai berdasarkan variabel bahasa yang dinyatakan dalam fungsi keanggotaan. Contoh dari himpunan variabel bahasa misalnya himpunan Fuzzy suhu yang terdiri atas 5 bagian keanggotaan, yaitu dingin, sejuk, normal, hangat, dan panas.

\section{Fungsi Keanggotaan}

Fungsi keanggotaan (membership function) merupakan sebuah kurva yang menunjukkan pemetaan titik-titik input data ke dalam nilai keanggotaannya yang memiliki rentang nilai 0 hingga 1. Cara untuk mendapatkan nilai keanggotaan adalah memanfaatkan pendekatan fungsi. Macam-macam fungsi yang dapat digunakan adalah sebagai berikut [6]:

- Representasi linear

- Representasi kurva segitiga

- Representasi kurva trapesium

- Representasi kurva bentuk bahu

\section{E. Internet of Things(IoT)}

IoT adalah teknologi yang memungkinkan sebuah perangkat terhubung ke jaringan internet untuk dimonitor atau dikendalikan dari jarak jauh oleh pengguna. Teknologi ini berfungsi untuk memonitor atau mengontrol suatu kondisi atau sesuatu yang dianggap penting dengan menggunakan sensor, seperti suhu udara, kelembapan, kebocoran air, atau kebakaran yang terjadi dalam ruangan atau rumah [7].

Salah satu contoh media yang digunakan untuk monitoring adalah website. Website adalah keseluruhan halaman-halaman web yang terdapat dalam sebuah domain yang mengandung informasi [8]. Berikut adalah elemen-elemen yang membangun sebuah website [9]:

1) Hypertext Markup Language (HTML)

HTML merupakan suatu script yang bisa menampilkan informasi dan daya kreasi kita melalui internet.

2) PHP Hypertext Processor (PHP)

PHP digunakan sebagai bahasa script server-side dalam pengembangan web yang disisipkan pada dokumen HTML.

3) $M y S Q L$

MySQL adalah sebuah program penghasil database yang dapat berjalan dengan sebuah aplikasi pengguna (interface). Aplikasi tersebut berfungsi untuk mengakses database yang dihasilkan oleh MySQL. MySQL juga menggunakan SQL sebagai bahasa dasar untuk mengakses database-nya sehingga mudah digunakan.

\section{PeRAnCANGan System}

\section{A. Perancangan Perangkat Keras}

Perancangan perangkat keras yang digunakan dalam membangun sistem ini terdiri atas rancangan elektrikal dan rancangan mekanikal. Untuk perancangan elektrikal, mikrokontroler berfungsi melakukan pengolahan data dari keseluruhan sistem yaitu berupa sensor dengan aktuator berupa motor DC $12 \mathrm{~V}$ dan Pompa Air $12 \mathrm{~V}$. Sedangkan komponen pendukung untuk melakukan monitor adalah SD card berfungsi sebagai media penyimpan ketika data terputus dan ethernet shiled sebagai media komunikasi dengan internet. Perhatikan Gambar 2.

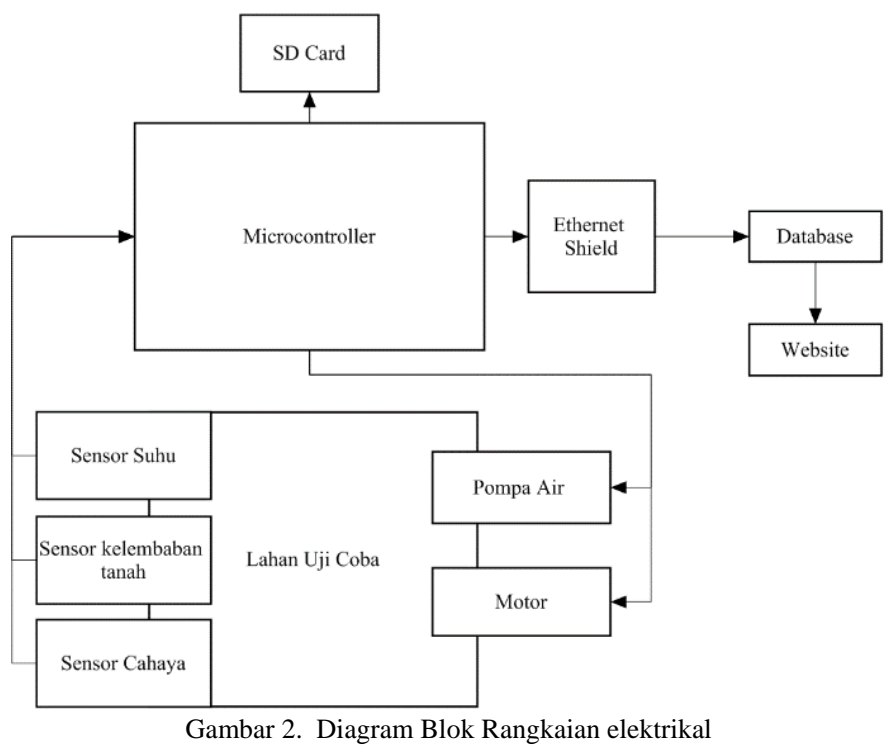

\section{B. Perancangan Mekanik}

Alat yang dibuat berbentuk kubus dengan 3 buah atap yang dihubungkan dengan rantai pada salah satu sisi yang bertujuan melakukan pergerakan secara serenta, serta sprinkler tanaman yang terletak ditengah agar penyemprotan dapat berjalan maksimal (Gambar 3). 


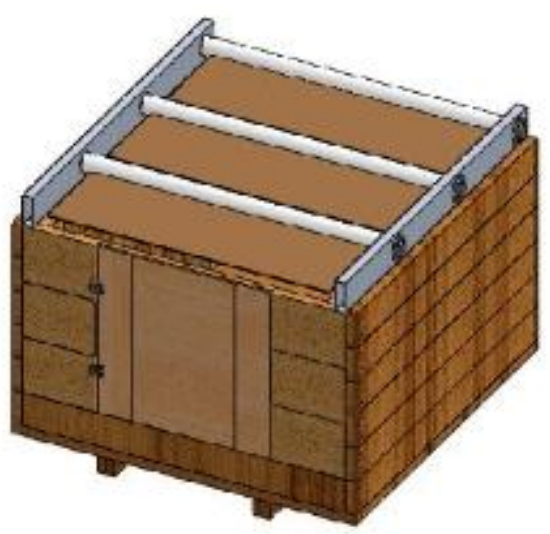

Gambar 3. Desain mekanik

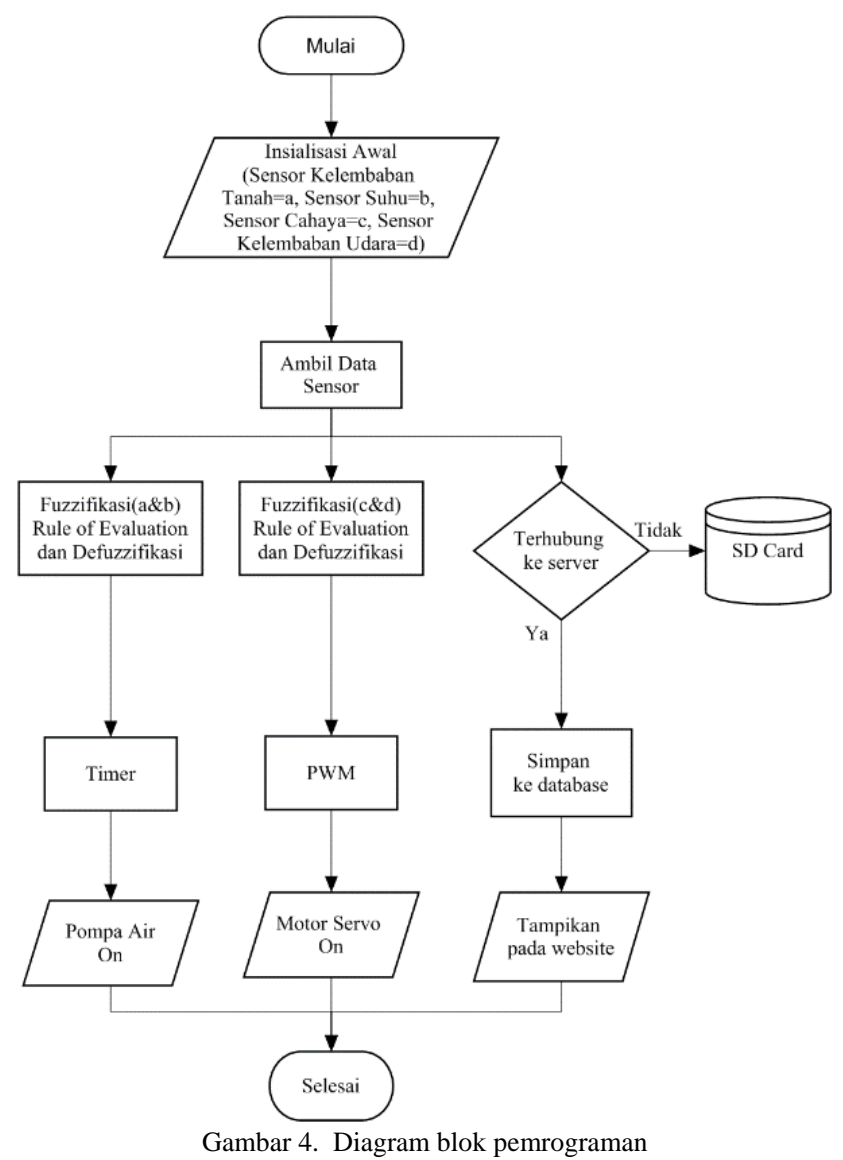

\section{Perancangan Perangkat Lunak}

Alur pemograman yang dibuat dijelaskan pada Gambar 4. Inisialisasi awal pada masing-masing sensor kemudian difungsikan sebagai pengambil data input dan diteruskan ke proses Fuzzy dan menuju pemeriksaan koneksi server. Kemudian, masing-masing Fuzzy akan memberikan nilai timer dan nilai Pulse Width Modulation (PWM) untuk pompa air dan motor pembuka. Selain itu, dalam pemeriksaan kondisi server akan terdapat pilihan apabila koneksi gagal dan koneksi berhasil. Jika gagal, maka akan tersimpan pada SD card dan disimpan ke database. Jika koneksi berhasil, maka akan diteruskan ke website.

\section{Perancangan Sistem Fuzzy}

Pembuatan logika Fuzzy melalui beberapa proses yaitu: Fuzifikasi dengan masing-masing parameter (Gambar 5-10) dan evaluasi aturan (Tabel I dan II). Nilai keanggotaan kelembapan tanah, intensitas cahaya, kelembapan udara, durasi penyiraman, dan luas pembukaan atap didasarkan pada intuisi penulis sesuai dengan kondisi lingkungan. Nilai keanggotaan kelembapan suhu udara didasarkan pada referensi ahli tanaman tomat [2].

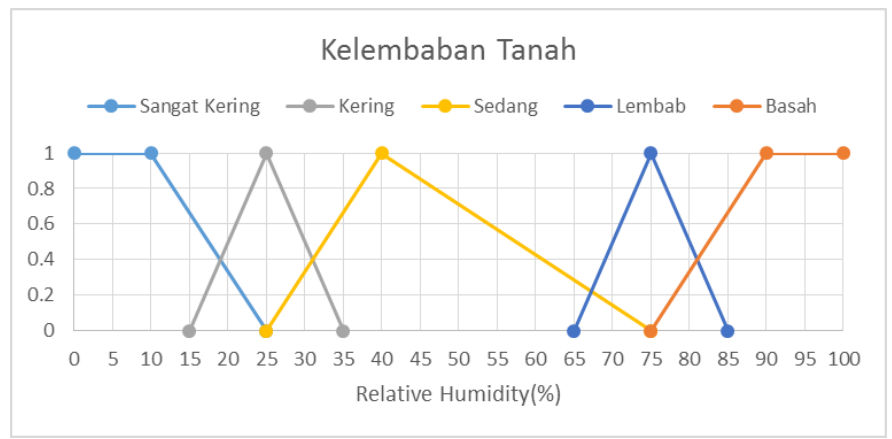

Gambar 5. Keanggotaan kelembapan tanah

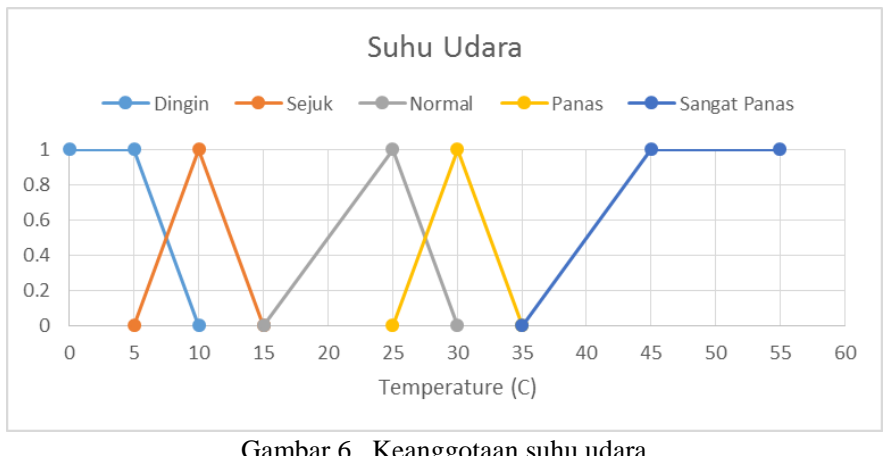

Gambar 6. Keanggotaan suhu udara

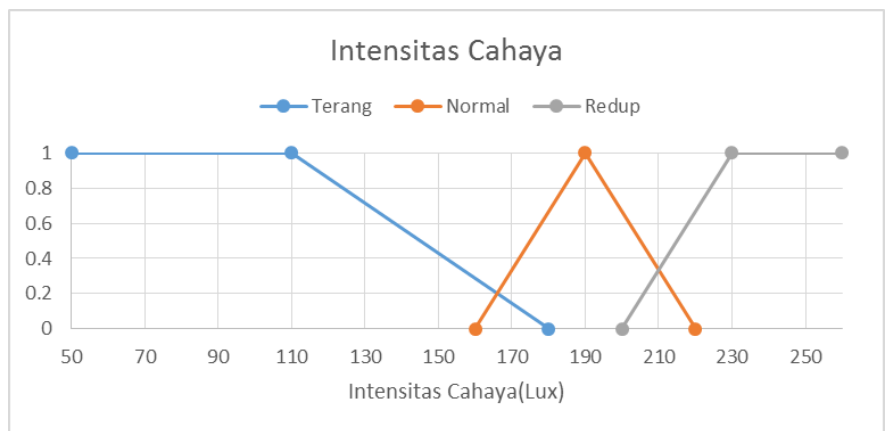

Gambar 7. Keanggotaan intensitas cahaya

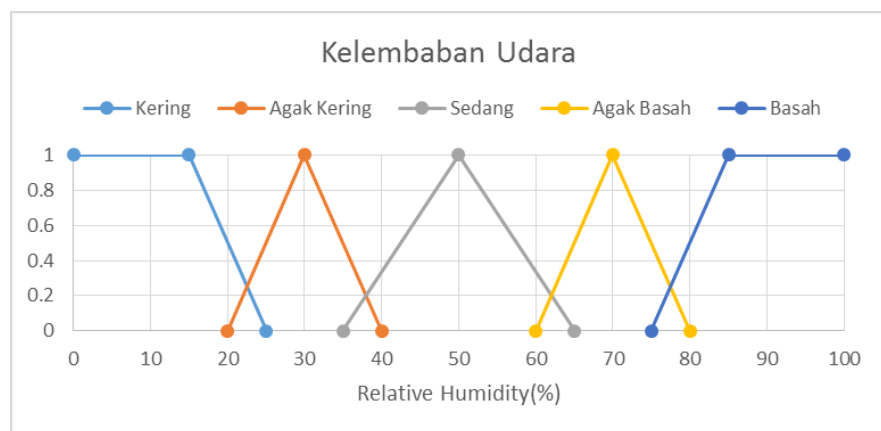

Gambar 8. Keanggotaan kelembapan udara 


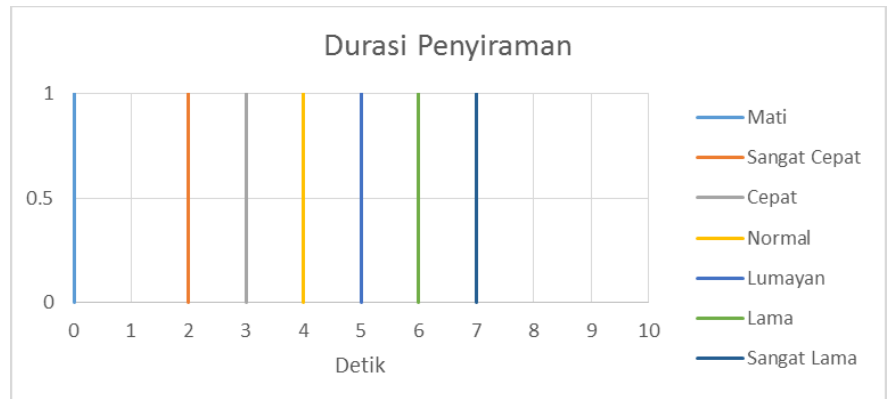

Gambar 9. Keanggotaan durasi penyiraman

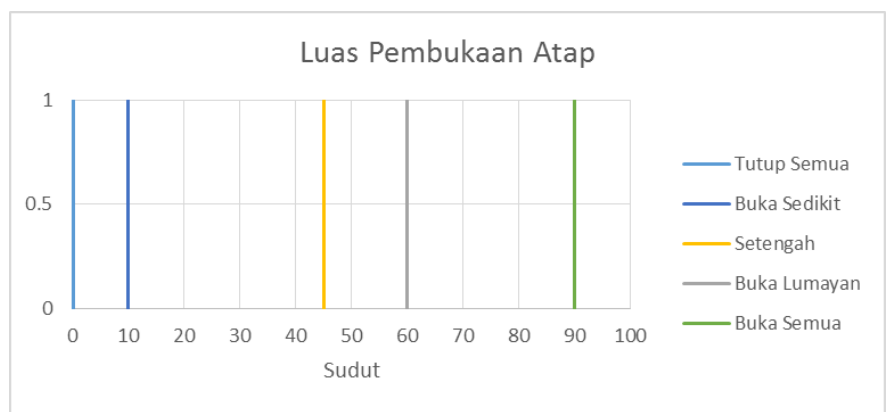

Gambar 10. Keanggotaan luas pembukaan atap

TABEL I

ATURAN SUHU UDARA DAN KELEMBAPAN TANAH

\begin{tabular}{|c|c|c|c|c|c|c|}
\hline \multirow{2}{*}{\multicolumn{2}{|c|}{$\begin{array}{c}\text { Kondisi } \\
\text { Lingkungan }\end{array}$}} & \multicolumn{5}{|c|}{ Kelembaban Udara } \\
\hline & & Kering & Agak Kering & Sedang & Agak Basah & Basah \\
\hline \multirow{3}{*}{$\begin{array}{l}\mathrm{C} \\
\mathrm{a} \\
\mathrm{h} \\
\mathrm{a} \\
\mathrm{y} \\
\mathrm{a}\end{array}$} & Redup & Buka Semua & $\begin{array}{c}\text { Buka Semua } \\
\left(90^{\circ}\right)\end{array}$ & $\begin{array}{c}\text { Lumayan } \\
\left(60^{\circ}\right)\end{array}$ & & \\
\hline & Norm & Sediki & & & edik & \\
\hline & $\mathrm{Te}$ & $\begin{array}{c}\text { tup Sem } \\
\left(0^{\circ}\right)\end{array}$ & & & $(9$ & Buka \\
\hline
\end{tabular}

TABEL II

EVALUASI ATURAN KELEMBAPAN UDARA DAN INTENSITAS CAHAYA

\begin{tabular}{|c|c|c|c|c|c|c|}
\hline \multirow{2}{*}{\multicolumn{2}{|c|}{ Kondisi Lingkungan }} & \multicolumn{5}{|c|}{ Suhu Udara } \\
\hline & & \multirow{2}{*}{\begin{tabular}{|c|}
$\begin{array}{c}\text { Sangat } \\
\text { panas }\end{array}$ \\
$\begin{array}{c}\text { Sangat } \\
\text { Lama(7s) }\end{array}$ \\
\end{tabular}} & \multirow{2}{*}{$\begin{array}{c}\text { Panas } \\
\begin{array}{c}\text { Lama } \\
(6 \mathrm{~s})\end{array}\end{array}$} & \multirow{2}{*}{$\begin{array}{c}\text { Normal } \\
\begin{array}{c}\text { Lumayan } \\
(5 \mathrm{~s})\end{array} \\
\end{array}$} & \multirow{2}{*}{ 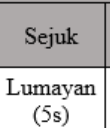 } & \multirow{2}{*}{$\begin{array}{c}\text { Dingin } \\
\begin{array}{c}\text { Normal } \\
(4 s)\end{array}\end{array}$} \\
\hline \multirow{5}{*}{ Kelembaban Tanah } & $\begin{array}{l}\text { Sangat } \\
\text { Kering }\end{array}$ & & & & & \\
\hline & Kering & Lama(6s) & $\begin{array}{c}\text { Lumayan } \\
(5 \mathrm{~s})\end{array}$ & $\begin{array}{c}\text { Normal } \\
(4 \mathrm{~s})\end{array}$ & $\begin{array}{c}\text { Cepat } \\
(3 \mathrm{~s})\end{array}$ & $\begin{array}{l}\text { Cepat } \\
(3 \mathrm{~s})\end{array}$ \\
\hline & Sedang & \begin{tabular}{|c|}
$\begin{array}{c}\text { Lumayan } \\
(5 \mathrm{~s})\end{array}$ \\
\end{tabular} & $\begin{array}{c}\text { Normal } \\
(4 s)\end{array}$ & $\begin{array}{l}\text { Cepat } \\
(3 \mathrm{~s})\end{array}$ & $\begin{array}{l}\text { Cepat } \\
(3 \mathrm{~s})\end{array}$ & $\begin{array}{c}\text { Sangat } \\
\text { Cepat(2s) }\end{array}$ \\
\hline & Lembab & $\begin{array}{c}\text { Sangat } \\
\text { Cepat }(2 s) \\
\end{array}$ & $\begin{array}{c}\text { Sangat } \\
\text { Cepat(2s) }\end{array}$ & $\begin{array}{l}\text { Cepat } \\
(3 \mathrm{~s})\end{array}$ & $\begin{array}{l}\text { Mati } \\
(0 \mathrm{~s})\end{array}$ & $\begin{array}{l}\text { Mati } \\
(0 \mathrm{~s})\end{array}$ \\
\hline & Basah & $\begin{array}{c}\text { Sangat } \\
\text { Cepat(2s) }\end{array}$ & $\begin{array}{c}\text { Sangat } \\
\text { Cepat(2s) }\end{array}$ & $\begin{array}{l}\text { Mati } \\
(0 \mathrm{~s})\end{array}$ & $\begin{array}{l}\text { Mati } \\
(0 \mathrm{~s})\end{array}$ & $\begin{array}{l}\text { Mati } \\
(0 \mathrm{~s})\end{array}$ \\
\hline
\end{tabular}

\section{PENGUJIAN DAN ANALISIS}

\section{A. Pengujian dan Analisis Fuzzy}

Pengujian dari Fuzzy dibagi menjadi 3, yaitu: 1) Fuzzy 1 (dengan nilai input berupa kelembapan tanah dan suhu udara dengan hasil output durasi penyiraman), 2) Fuzzy 2 (dengan nilai input intensitas cahaya dan kelembapan udara yang memiliki output luas pembukaan atap), dan 3) pengujian koneksi pengiriman data menuju website. Berdasarkan hasil yang didapat, nilai output Fuzzy 1 memiliki error yang tidak begitu besar dengan rata-rata error keseluruhan sebesar $0,2 \%$. Selain itu, keberhasilan pengiriman data hanya terkendala pada pengiriman pertama dimana koneksi terputus akibat syarat pengiriman data harus memiliki durasi 5 menit setelah arduino aktif (Tabel III dan IV).

TABEL III

HASIL OUTPUT FUZZY 1

\begin{tabular}{|c|c|c|c|c|}
\hline No & $\begin{array}{c}\text { Kelembaban } \\
\text { Tanah (\%) }\end{array}$ & $\begin{array}{c}\text { Suhu Udara } \\
(\text { Celcius })\end{array}$ & $\begin{array}{c}\text { Pompa Air } \\
(\text { Detik })\end{array}$ & $\begin{array}{c}\text { Pompa Air } \\
\text { (Nilai } \text { Fuzzy })\end{array}$ \\
\hline 1 & 85 & - & - & - \\
\hline 2 & 84 & 26.7 & 0 & 3.25 \\
\hline 3 & 84 & 26.6 & 0 & 3.21 \\
\hline 4 & 83 & 26.7 & 0 & 4.48 \\
\hline 5 & 83 & 26.7 & 0 & 4.48 \\
\hline 6 & 83 & 26.7 & 0 & 4.48 \\
\hline 7 & 83 & 26.6 & 0 & 4.47 \\
\hline 8 & 83 & 26.5 & 0 & 4.46 \\
\hline 9 & 83 & 26.3 & 0 & 4.44 \\
\hline 10 & 82 & 26.4 & 2 & 5.5 \\
\hline 11 & 82 & 26.4 & 2 & 5.5 \\
\hline 12 & 82 & 26.5 & 2 & 5.49 \\
\hline 13 & 82 & 26.5 & 2 & 5.49 \\
\hline 14 & 82 & 26.5 & 2 & 5.49 \\
\hline 15 & 82 & 26.4 & 2 & 5.5 \\
\hline 16 & 82 & 26.2 & 2 & 5.53 \\
\hline 17 & 82 & 26.2 & 2 & 5.53 \\
\hline 18 & 82 & 26.1 & 2 & 5.55 \\
\hline 19 & 82 & 26.1 & 2 & 5.55 \\
\hline 20 & 82 & 26.1 & 2 & 5.55 \\
\hline Rata-rata & 82.53 & 26.43 & 1.16 & 4.94 \\
\hline & & & & \\
\hline
\end{tabular}

TABEL IV

HASIL PERHITUNGAN FUZZY 1

\begin{tabular}{|c|c|c}
\hline $\begin{array}{c}\text { Perhitungan } \\
\text { Fuzzy }\end{array}$ & Error & Connection \\
\hline- & - & Not connected \\
\hline 3.245614 & 0.00135 & Success \\
\hline 3.2142857 & 0.00133 & Success \\
\hline 4.4764398 & 0.00079 & Success \\
\hline 4.4764398 & 0.00079 & Success \\
\hline 4.4764398 & 0.00079 & Success \\
\hline 4.4680851 & 0.00043 & Success \\
\hline 4.4594595 & 0.00012 & Success \\
\hline 4.4413408 & 0.0003 & Success \\
\hline 5.5025126 & 0.00046 & Success \\
\hline 5.5025126 & 0.00046 & Success \\
\hline 5.4878049 & 0.0004 & Success \\
\hline 5.4878049 & 0.0004 & Success \\
\hline 5.4878049 & 0.0004 & Success \\
\hline 5.5025126 & 0.00046 & Success \\
\hline 5.5347594 & 0.00086 & Success \\
\hline 5.5347594 & 0.00086 & Success \\
\hline 5.5524862 & 0.00045 & Success \\
\hline 5.5524862 & 0.00045 & Success \\
\hline 5.5524862 & 0.00045 & Success \\
\hline 4.95 & 0 & Success \\
\hline
\end{tabular}

Hasil Fuzzy 2 antara kelembapan udara dan intensitas cahaya menghasilkan error yang juga tidak terlalu besar yaitu 0,2\% (sama dengan hasil pada Fuzzy 1). Perbedaan terjadi pada kelembapan udara yang masih stabil pada kondisi 99,99\%. Hal ini terjadi akibat kelembapan udara yang sangat sulit diturunkan kadarnya namun sangat mudah ditingkatkan saat berada di ruang uji coba. Koneksi pengiriman data pada 
Fuzzy 2 sama dengan Fuzzy 1(Tabel V dan VI).

TABEL V

HASIL OUTPUT FUZZY 2

\begin{tabular}{|c|c|c|c|c|}
\hline No & $\begin{array}{c}\text { Kelembaban } \\
\text { Udara (\%) }\end{array}$ & $\begin{array}{c}\text { Intensitas } \\
\text { Cahaya (lux) }\end{array}$ & $\begin{array}{c}\text { Atap } \\
\text { (Sudut) }\end{array}$ & $\begin{array}{c}\text { Atap (Nilai } \\
\text { Fuzzy) }\end{array}$ \\
\hline 1 & - & 225.81 & - & - \\
\hline 2 & 99.9 & 221.15 & 10 & 14.98 \\
\hline 3 & 99.9 & 221.15 & 10 & 14.98 \\
\hline 4 & 99.9 & 220.39 & 10 & 14.99 \\
\hline 5 & 99.9 & 220.39 & 10 & 14.99 \\
\hline 6 & 99.9 & 221.15 & 10 & 14.98 \\
\hline 7 & 99.9 & 220.39 & 10 & 14.99 \\
\hline 8 & 99.9 & 221.15 & 10 & 14.98 \\
\hline 9 & 99.9 & 220.39 & 10 & 14.99 \\
\hline 10 & 99.9 & 221.15 & 10 & 14.98 \\
\hline 11 & 99.9 & 221.91 & 10 & 14.98 \\
\hline 12 & 99.9 & 221.15 & 10 & 14.98 \\
\hline 13 & 99.9 & 221.15 & 10 & 14.98 \\
\hline 14 & 99.9 & 221.15 & 10 & 14.98 \\
\hline 15 & 99.9 & 220.39 & 10 & 14.99 \\
\hline 16 & 99.9 & 221.15 & 10 & 14.98 \\
\hline 17 & 99.9 & 220.39 & 10 & 14.99 \\
\hline 18 & 99.9 & 219.64 & 10 & 14.72 \\
\hline 19 & 99.9 & 221.15 & 10 & 14.98 \\
\hline 20 & 99.9 & 220.39 & 10 & 14.99 \\
\hline Rata-rata & 99.9 & 220.83 & 10 & 14.97 \\
\hline
\end{tabular}

TABEL VI HASIL PERHITUNGAN FUZZY 2

\begin{tabular}{|c|c|c|}
\hline $\begin{array}{c}\text { Perhitungan } \\
\text { Fuzzy }\end{array}$ & Error & Connection \\
\hline- & - & Not connected \\
\hline 15 & 0.00133333 & Success \\
\hline 15 & 0.00133333 & Success \\
\hline 15 & 0.00066667 & Success \\
\hline 15 & 0.00066667 & Success \\
\hline 15 & 0.00133333 & Success \\
\hline 15 & 0.00066667 & Success \\
\hline 15 & 0.00133333 & Success \\
\hline 15 & 0.00066667 & Success \\
\hline 15 & 0.00133333 & Success \\
\hline 15 & 0.00133333 & Success \\
\hline 15 & 0.00133333 & Success \\
\hline 15 & 0.00133333 & Success \\
\hline 15 & 0.00133333 & Success \\
\hline 15 & 0.00066667 & Success \\
\hline 15 & 0.00133333 & Success \\
\hline 15 & 0.00066667 & Success \\
\hline 15 & 0.01866667 & Success \\
\hline 15 & 0.00133333 & Success \\
\hline 15 & 0.00066667 & Success \\
\hline 15 & 0 & Success \\
\hline & & \\
\hline
\end{tabular}

\section{B. Pengujian dan Analisis IoT}

Pengujian IoT bertumpu pada konektivitas antara arduino dengan website. Berdasarkan data yang diperoleh (Gambar 11 dan 12), koneksi menuju website berjalan dengan baik. Hal ini terbukti dengan terkirimnya keseluruhan data dari pembacaan sensor yang memenuhi syarat (durasi pembacaan arduino). Koneksi tersebut dapat berjalan lancar disebabkan beberapa faktor, seperti kondisi sinyal 3G dari operator GSM, kondisi kuota yang masih tercukupi dan kondisi listrik yang menyala. Meskipun demikian, masih terdapat keterlambatan dalam pengiriman data dengan dengan waktu minimal keterlambatan 3 detik dan maksimal 4 detik.

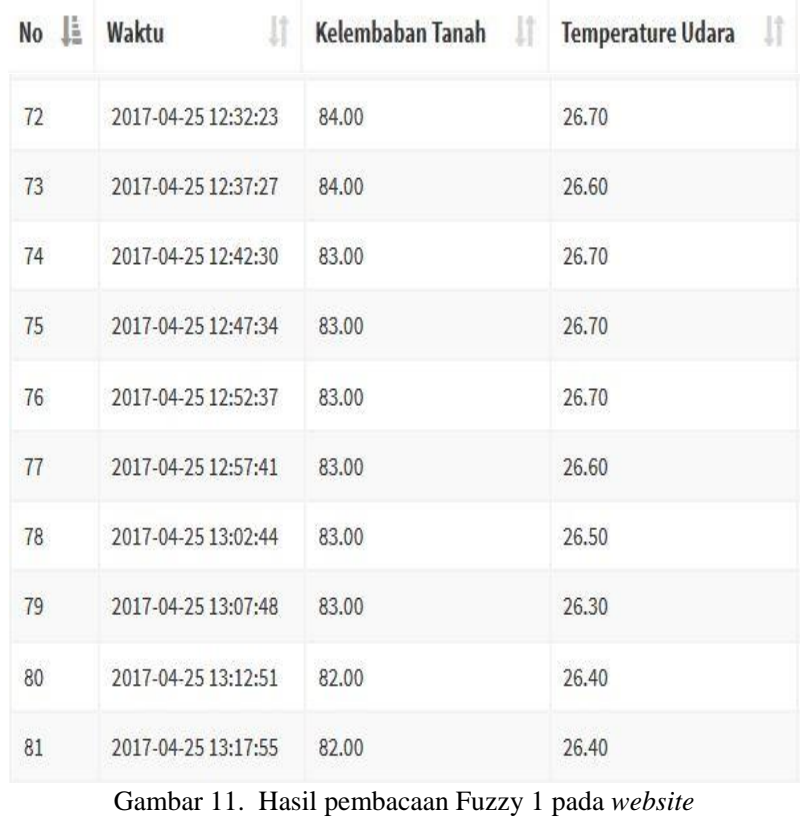

\begin{tabular}{|l|l|l|l|}
\hline No & Waktu & Kelembaban Udara & If \\
\hline 72 & $2017-04-2512: 32: 23$ & 99.90 & 221.15 \\
\hline 73 & $2017-04-2512: 37: 27$ & 99.90 & 221.15 \\
\hline 74 & $2017-04-2512: 42: 30$ & 99.90 & 220.39 \\
\hline 75 & $2017-04-2512: 47: 34$ & 99.90 & 220.39 \\
\hline 76 & $2017-04-2512: 52: 37$ & 99.90 & 221.15 \\
\hline 77 & $2017-04-2512: 57: 41$ & 99.90 & 220.39 \\
\hline 78 & $2017-04-2513: 02: 44$ & 99.90 & 221.15 \\
\hline 79 & $2017-04-2513: 07: 48$ & 99.90 & 220.39 \\
\hline 80 & $2017-04-2513: 12: 51$ & 99.90 & 221.15 \\
\hline 81 & $2017-04-2513: 17: 55$ & 99.90 & 221.91 \\
\hline & Gambar 12. Hasil pembacaan Fuzzy 2 pada website
\end{tabular}

\section{KESIMPULAN}

Berdasarkan hasil dari penilitan dan kinerja keseluruhan sistem maka, dapat disimpulkan bahwa logika Fuzzy berjalan sesuai dengan aturan yang telah dibuat. Website yang dibuat dapat berjalan sesuai dengan fungsinya sebagai media pemantau. Kondisi tanaman tomat dengan perawatan secara alami lebih baik daripada secara otomatis dengan rata-rata tinggi tanaman yang melalui perawatan secara manual sebesar $8,62 \mathrm{~cm}$ serta rata-rata tinggi tanaman melalui perawatan secara otomatis sebesar $1,92 \mathrm{~cm}$. Cakupan pembacaan sensor DHT22 dan FC-28 terbatas sehingga tidak semua lingkungan dapat terbaca kondisinya. Range Fuzifikasi (input) yang terlalu luas mengakibatkan perubahan kondisi 
lingkungan yang sedikit tidak terlalu berpengaruh terhadap output. Tingkat keberhasilan dari alat mencapai 98,38\% meliputi uji coba Fuzzy, website dan sensor.

\section{REFERENSI}

[1] Catur Wasonowati, "Meningkatkan Pertumbuhan Tanaman Tomat (Lycopersicon Esulentum) dengan Sistem Budidaya Hidroponik," Jurnal Agroekoteknologi, vol. 4, no. 1, pp. 21-27, 2011.

[2] (2012, June) Balai Besar Pelatihan Pertanian Lembang. [Online]. www.bbpp-lembang.info

[3] Akhmad Akbar Yudha Trisna, "Instrumen Ukur Kadar Kebutuhan Pupuk Urea pada Tanaman Jagung Menggunakan Metode Fuzzy Logic," Universitas Jember, Jember, Skripsi 2013.

[4] Sumantri Kurniawan Risandriya. (2016, October) Rule Evaluation. Modul Pembelajaran.

[5] Muhammad Aulia Rahman, "Studi Komparasi Beberapa Kaidah Kontrol Logika Fuzzy untuk Parkir Mobil Seri Otomatis secara Simulasi Menggunakan LabView," Unikom, Bandung, Tugas Akhir 2013.

[6] Leo Agusman, Shuandy Wijaya, and Yakobus Ingo, "Aplikasi Logika Fuzzy untuk Analisis Tes Kepribadian," Binus University, Jakarta, Skripsi 2009.

[7] Dias Prihatmoko, Widyawan, Selo, and Sigit Basuki Wibowo, "Pengembangan Perangkat Lunak Gateway untuk Home Automation Berbasis IQRF TR53B Menggunakan Konsep CGI," in Seminar Nasional Sistem Informasi Indonesia, Bali, 2013, pp. 605-611.

[8] Mooduto Yuhefizar and Rahmat Hidayat, Cara Mudah Membangun Website Interaktif Menggunakan Content Management System. Jakarta, Indonesia: Elex Media Komputindo, 2009.

[9] Susy Kusuma Wardani, "Sistem Informasi Pengolahan Data Nilai Siswa Berbasis Web pada Sekolah Menengah Kejuruan (SMK) PGRI 1 Pacitan," Indonesian Journal of Network \& Security, vol. 2, no. 4, pp. 12-19, 2013. 